\title{
The Public Value of Government ICT Investments: Foundations and Applications
}

\author{
Anthony Cresswell \\ Center for Technology in Government \\ University at Albany, USA \\ tcresswell@ctg.albany.edu
}

\begin{abstract}
Keynote Speech. This paper discusses the concept of public value in relation to government ICT investment from three perspectives -theory foundations, assessment methods, and an application example. The discussion of theory foundations combines attention to the roots of the concept of public value in political philosophy and public administration. The origins of the concept of public value are discussed in terms of foundational ideas in political and moral philosophy about the nature of the good society: utilitarianism and the social contract. The concern with public value, or utility, in early Western moral and political philosophy is central to the two major schools of thought, utilitarian and social contractarian. The social order that produces the greatest good or utility for the greatest number is preferred in the utilitarian perspective. The contractarian view holds that a good society should be based on shared principles and arrangements that avoid the potential evils of unconstrained greed. Though these two views political and moral philosophy differ, they weave similar connections among the basic concept of value, individual interests, societal interests, and institutional forms. These concepts and connections are basic to the public value framework .

The framework links value to the workings of government in terms of individual and group interests in relation to government policies and programs. this view is reflected in recent thinking in public administration, particularly in the public value program described by Moore (1995). In Moore's terms, "value is rooted in the desires and perceptions of individuals-not necessarily in physical transformations, and not abstractions called societies." (p. 52) Moore includes both public sector production, i.e., "things of value to particular clients and beneficiaries," and "establishing and operating an institution that meets citizens' (and their representatives') desires for properly ordered and productive public institutions." (Moore, 1995:53)

These foundational ideas then form the basis for an assessment method and framework designed to operationalize and provide useful data about the public value outcomes of government investment decisions. The paper presents a description of the assessment framework, followed by an example of how the method applies to a specific ICT investment in a government human service program. A discussion of the implications of the public value framework for investment and performance assessment concludes the paper.
\end{abstract}

